\title{
BASIC WATER RIGHTS DOCTRINES AND THEIR IMPLICATIONS FOR RIVER BASIN DEVELOPMENT
}

\author{
Wells A. Hutchins* and Harry A. Steele†
}

\section{InTRODUCTION}

In transmitting the report of his Advisory Committee on Water Resources Policy, the President stated that "the policies we adopt for the development of our water resources will have a profound effect in the years to come upon our domestic, agricultural and industrial economy." The report estimates that the demand for water in the nation will almost double by 1975 and that there must be a substantial increase in the beneficial use of water. ${ }^{2}$ This will require increased development by individuals and corporations, as well as by public agencies.

The river basin is now generally accepted as the appropriate physiographic unit for planning and developing water resource utilization. The interrelated and competing uses of water within a river basin, however, often give rise to varied and complex problems that appear susceptible of solution only by the integrated action of all interests, public and private, within the basin's natural boundaries. ${ }^{3}$ Thus, while group development of water resources has always been important, new impetus has been given to watershed, small project, ground-water basin, multipurpose project, and river and interriver basin programs, which appear to promise greater efficacy than development undertaken on an individual basis. State water laws, which have been framed with reference to individual action in developing water resources in the past, may not, accordingly, be adequate for the future.

In this connection, several important and troublesome areas have been pointed out. ${ }^{4}$ The increasing consumptive use of water in the riparian-doctrine eastern states, for example, has created an interest in the appropriation doctrine as it might apply there. The shifting demand for water similarly has raised problems in the appropria-

* LL.B. 1909, George Washington University. Agricultural Economist, United States Department of Agriculture. Lecturer in Irrigation, University of California, 1950, 1952-56. Author, Sezected PronIEMS in the LaW of Water Rights in the West (1942), The Hawainan System of Waten Rights (1946), The California Law of Water Righrs ( 1956 ); booklets on the law of water rights in Nevada (1955), New Mexico (r955), Oklahoma (1955), Idaho (r956), Kansas (1957); and various works on irrigation institutions and water law. Contributor to legal periodicals.

†B.S. I931, M.S. 1932, South Dakota State College. Ifead, Land and Water Section, Farm Economics Research Division, Agricultural Research Service, United States Department of Agriculture. Formerly, Assistant Exccutive Director, Missouri Basin Survey Commission.

${ }^{1}$ Presidential Advisory Comm. on Water Resources Policy, Water Resources Policy iv (1955).

Id. at 5 .

${ }^{8}$ See Steele and Regan, Organization and Administrative Arrangements for an Effective Water Policy, 37 J. FARM Econ. 886 (r955).

“See, e.g., Wantrup, Some Economic Issues in Water Rights, 37 J. FARM EcoN. 875 (1955). 
tion states. A great expansion in the use of ground water, moreover, has posed problems that neither doctrine seems to answer. And large-scale multiple-purpose projects have created novel problems of reshuffing rights of use between users and uses, between watersheds, and between states.

This article will first briefly review the existing water law-the riparian and appropriation doctrines; and since most of the adjustment of these two doctrines has occurred in the western states, attention will necessarily be focused on that area. Then, it will examine some of the problems arising from the relation of these doctrines to river basin development.

II

The Legal Context

A. Classifications of Water ${ }^{5}$

Legal distinctions between waters on the surface of the earth and those beneath the surface and between defined classes of subterranean waters have been drawn since early times. In the laws of some western states, these distinctions have been abolished, but in probably the great majority of American jurisdictions, they still persist, and so it is necessary to take account of them in discussing water rights doctrines.

\section{Surface Watercourses}

A watercourse consists essentially of a definite natural stream, flowing in a definite natural channel, and originating from a definite source of supply; and it includes the underflow. ${ }^{6}$ The two basic systems of rights to the use of water of watercourses are related, respectively, to the riparian and the appropriation doctrines.

\section{Diffused Surface Waters}

Waters that originate from rain and melting snow and that flow vagrantly over the surface before concentrated in watercourses or before sinking into the ground are diffused surface waters-often loosely called surface waters. A considerable body of law has grown up with respect to the avoidance or riddance of such waters; much less as to rights of use. Generally, the owner of land on which such water occurs is considered entitled to capture and use it while it is still on his land. There is little authority, however, as to the relationship between such a right of capture and use and the right of a riparian landowner or appropriator on a stream into which the diffused surface water would flow if not intercepted. This aspect of river basin development

'Sec, generally, 2 S. C. Wiel, Water Rights in the Western States, $\$ \S$ ro39-I75 (3d ed. I9II); 2 C. S. Kinney, A Treatise on the LaW of Irrigation and Water Rights $\$ \$ 1$ I 4 8-21 (2d ed. I9I2); Thompson and Fiedler, Some Problems Relating to Legal Control of Use of Ground Waters, 30 J. AM. Water Worxs Ass'N 1049 (1938); Tolman and Stipp, Analysis of Legal Concepts of Subflow and Percolating Waters, ro6 Trans. Am. Soc'y Civ. Eng. 882 (1941); Wells A. Hutchins, Selected Problems iN the LAW OF Water Rights in the West 146-265 (U. S. Dep't of Agriculture Misc. Pub. No. 4I8, I942); C. L. McGuinness, Water Law with Special Reference to Ground Water (U. S. Geol. Survey Circ. No. 17, 1951).

'See I WIEL, op. cit. supra note $5, \S 333$.

${ }^{7}$ See Hutchins, op. cit. stipra note 5 , at $110-45$. 
may become important as more land is included in managed watersheds, but the legal principles that will govern it have yet to be formulated.

\section{Ground Waters: Definite Underground Streams}

A definite underground stream has the essential characteristics of a surface watercourse, except that it is buried in the ground. Necessarily, proof of physical aspects is difficult. Some courts insist on establishment of all elements with reasonable certainty; others accept determinations by reasonable inference. Rights to the use of definite underground streams are governed by the law of watercourses-by the riparian or the appropriation doctrines, or both of them concurrently.

\section{Ground Waters: Underflow of Surface Streams}

Underneath a surface stream, there is usually an underflow or subflow. This consists of water in the sands, gravels, and other subsoil over which the surface stream flows, moving in the same direction and in intimate contact with the surface stream. The boundaries may extend laterally for considerable distances beyond the banks of the surface channel. From a legal as well as a physical standpoint, the surface stream and the underflow are not two separate rivers, but are component parts of a single watercourse. ${ }^{9}$ Rights to the use of the underflow are governed by the law of watercourses, therefore, just as are rights in the surface flow; and rights that attach to a watercourse include rights in its underflow. ${ }^{10}$

\section{Ground Waters: Percolating Waters}

In determining rights of use, percolating water is usually considered to be subsurface water that is free to move by gravity and, hence, to enter wells, but not concentrated in what the law classifies as a definite underground stream or as underflow of a surface stream. ${ }^{11}$ As in the case of watercourses, rights to the use of percolating waters fall into the two general groups: rights inherent in contiguous land, and those based on priority of diversion and use. The former group has several subdivisions: the English or common-law rule of absolute ownership, the American rule of reasonable use, and the doctrine of correlative rights. ${ }^{12}$

\section{B. The Basic Doctrines}

In discussing more fully the basic doctrines, to which some allusion has already been made, each of the several principal types of water rights, unless otherwise indicated, will be treated as though it were the only kind of water right in the community. Later, there will be separately considered the matter of conflicts of water rights in areas in which rights of opposing kinds are recognized.

\section{r. Nature of the Doctrines}

a. Watercourses. Where the riparian doctrine is in effect, the owner of a tract of

\footnotetext{
${ }^{8}$ See 2 Kinney, op. cit. supra note $5, \$ \$ 1156-60$.

- See Kansas v. Colorado, 206 U. S. 46, I I4-15 (1907).

${ }^{10}$ See 2 KINNEY, op. cit. supra note $5, \$ \$ 1161-63$.

${ }^{11}$ See 2 WIEL, op. cit. supra note $5, \$ 1084$.

${ }^{12}$ See 2 id., $\$ \$ 1039-66$.
} 
land contiguous to the channel of a surface stream-called riparian land-has certain rights in the flow of the stream. He may divert what water he needs for domestic use. For irrigation and other commercial purposes, each proprietor's use of water must be reasonable with respect to the requirements of all others. The same principle applies to the ownership of land that overlies an underground stream or the underflow of a surface stream. In each case, by operation of law, the water right arises out of the contiguity of land and water supply. But a limited use of the water on nonriparian land may be permitted in some states, particularly if other riparian owners incur no present or foreseeable damage. ${ }^{13}$ This nonriparian use may be considered an appropriation, or a use without formal right, however, rather than an exercise of the riparian right.

The appropriation doctrine, on the other hand, gives no preference to use of the water on land solely because of its contact with the water supply. Under this doctrine, the earliest right that attaches to a particular watercourse has preference over all later rights when the water supply is not enough for them all, whether the land on which the water is applied is adjacent to the stream or many miles away. This preference right is known as a priority, and the date on which the right accrues is the date of priority. ${ }^{\mathbf{1 4}}$ Needless to say, the priority of an appropriative right is, in itself, valuable property. By contrast, the riparian landowner who first begins to use water gains no preference over other riparian landowners solely because of his earlier use.

The riparian doctrine is generally followed in the eastern states. ${ }^{15}$ Of the seventeen western states, it is recognized, to a greater or lesser degree, in the six states that extend from North Dakota to Texas on the rooth meridian and in the three states that border the Pacific Ocean; in the others, it has been completely repudiated. ${ }^{16}$ The appropriation doctrine is a part of the water law of each of the seventeen western states, ${ }^{17}$ and some application of this doctrine is likewise made in the statutes of a few eastern states. ${ }^{18}$ It follows, therefore, that in some states, the riparian and appropriation doctrines are in effect concurrently. 19

b. Percolating ground waters. ${ }^{20}$ The English rule of absolute ownership allows the overlying landowner to abstract ground water from his land at any time and in any quantity, regardless of the effect on the water table in his neighbor's land. Any recession of the water table, even to the point of exhaustion of the supply, caused

${ }^{30}$ See J. R. Long, a Treatise on the Law of Irrigation \$3i (2d ed. I9i6).

"See, e.g., Hewitt v. Story, 64 Fed. 5Io, 5I $4^{-1} 5$ (9th Cir. I894).

${ }^{15}$ See Ellis, Some Current and Proposed Water-Rights Legislation in the Eastern States, $4 \mathrm{r}$ Iowa L. REv. 237 (1956); McGuINNEss, op. cit. supra note 5.

${ }^{10}$ See Hurchiss, op. cit. supra note 5 , at $42-44$.

${ }^{17}$ See $i d$. at 74 .

${ }^{18}$ E.g., Miss. Code ANN. $\$ \$ 5956-01$ to $5956-30$ (Supp. 1956). See also Ellis, supra note 15, at 238.

$10 \mathrm{Cf}$. Nat'l Resources Planning Board, Subconmittee on State Water Law, State Watek LAW in THE DEvelopMeNT OF THE WeST 99-III (I943).

${ }^{30}$ See particularly 2 WIEL, op. cit. supra note 5, §\$1039-66; 2 KINNEY, op. cit. supra note 5, $\$ \S 1185-$ $21 \mathrm{I}$; Thompson and Fiedler, supra note 5; McGurnness, op. cit. supra note 5; Hutchins, Trends in the Statutory Law of Ground Water in the Western States, 34 Tex. L. Rev. 158 (1955). 
by the heavy pumping of any overlying owner is damnum absque injuria. In some jurisdictions, this "absolute" rule is qualified by the requirement that the use of the percolating water be not malicious and, in some instances, not wasteful.

The American rule of reasonable use recognizes that the landowner has rights in the water underlying his land, but not unlimited rights. His use of the water must bear some reasonable relationship to the use of the overlying land. Unreasonable uses have been held to include export of ground water from the area that results in impairment of reasonable uses by other overlying landowners and waste of water.

The doctrine of correlative rights has not been clearly distinguished in some jurisdictions from the rule of reasonable use. In California, where correlative rights have been most extensively litigated, their basis is reasonable use, with added elements of coequality of right and apportionment of water in time of shortage.

The English doctrine is followed in some states, both eastern and western. In many jurisdictions, however, it has been replaced by the American rule of reasonable use or by the reasonable use rule as expanded to include aspects of correlative rights. In addition, in a considerable number of western jurisdictions, the appropriative principle has been applied by statute, court decision, or both to rights to use of percolating waters.

\section{Origin of the Doctrines}

a. The riparian doctrine. This doctrine came to America from the Roman law by several lines of descent. It was introduced into Texas by the Spanish and Mexican governments, which, in many grants of land, included rights in waters flowing through or adjacent to the grants. Thus, there was brought to the New World the riparian philosophy of the Spanish civil law and of the Roman law from which it was derived; and the policy of granting lands together with rights in adjacent waters was continued by the súcceeding governments of the Republic and State of Texas until late in the nineteenth century. ${ }^{21}$ On the other hand, the supreme courts of Arizona and New Mexico have declared that in those jurisdictions the riparian doctrine has never existed. ${ }^{22}$

Riparian principles of the French civil law, which were also based on the Roman law, were imported to the Atlantic seaboard by two eminent jurists, Story and Kent, in the early part of the nineteenth century. ${ }^{23}$ After Kent and Story had taken the riparian doctrine from the French sources, the courts of England adopted it as a part of their common law, and in so doing, they placed chief reliance on these American authorities. ${ }^{24}$ Thereafter, this doctrine became part of the law of numerous American jurisdictions by reason of their adopting the common law as the rule of decision in state and territorial courts.

\footnotetext{
${ }^{21}$ See Davenport, Riparian vs. Appropriative Rights: The Texas Experience, in Proceedincs of tHe Water Law Conferences, University of Texas 138 (1954); Mann, Riparian Irrigation Rights as Declared and Enforced by the Courts, and Protected by the Statutes, of Texas, in id. at 169.

${ }_{22}$ Clough v. Wing, 2 Ariz. 371, 381, 17 Pac. 453 (1888); Snow v. Abalos, 18 N. Mex. 68r, 693, 140 Pac. 1044 (1914).

${ }^{23}$ See Wiel, Waters: American Law and French Authority, 33 Harv. L. Rev. 33 (1919).

${ }^{24}$ See $i d$. at $144-47$.
} 
b. The appropriation doctrine. This doctrine has various antecedents, both ancient and modern. Views as to the origin of the principle in the Southwest conflict. One is that it had its roots in the civil law of Rome; ${ }^{25}$ another, that such "appropriations" arose only as a result of grants of water or of local custom based on prescription. ${ }^{26}$ In any event, the principle of exclusive rights in the use of water for lands, regardless of contiguity to streams, materially influenced the development of water law in several states in which the Spaniards and Mexicans had made settlements.

At the middle of the nineteenth century, the Mormons, on public lands in Utah, developed a system of appropriation of their own. By community action, they diverted water from streams and applied it to lands in order to produce the food they needed. When conflicts over the use of inadequate water supplies arose, the Mormons applied the principle of priority in time of beginning use of the water. ${ }^{2 \pi}$

During this period also, gold was discovered in the Sierra foothills of California on what were then Mexican public lands but which shortly afterward became part of the public domain of the United States. Miners flocked there from many states and foreign countries. They improvised local rules and regulations for taking and holding mining claims and claims to the use of water for working the mines, with the rule of priority applying to both land and water. ${ }^{28}$ These customs were strikingly characteristic of those followed by the Germanic miners in the Middle Ages, which later spread to various European countries and their colonies. ${ }^{29}$ Possibly the development of the appropriation doctrine in the California gold fields, instead of being altogether spontaneous, was influenced by what had transpired in other mining regions of the world. Nevertheless, the customs so established became statutory law in various states and territories of the West.

c. Percolating water doctrines. The rule of absolute ownership of percolating water is usually traced to an English decision rendered in I843, although at least one early American decision adopted practically the same general principle. ${ }^{30}$ The American rule of reasonable use originated in the eastern states, and out of it grew the correlative doctrine. ${ }^{31}$

\section{Formal Law}

All in all, a considerable body of American law, both statutory and judicial, relates to water rights. The riparian doctrine of surface water rights and the rules of ground water rights based on ownership of land, as recognized in the United States, are composed almost entirely of judicial law. Statutes that purport to affirm the existence

${ }^{35}$ See Nat's Reclamatton Ass'n, Report and Recommendations, Preservation of Integrity of State WATER LaWS 165-68 (1943).

${ }^{20}$ See Mann, supra note 2I, at 172.

${ }^{27}$ Sce I KINNEX, op. cit. supra note $5, \$ 243$.

${ }^{29}$ See I Wiel, op. cit. silpra note 5, $§ 68-7 I ;$ S. T. Harding, Water Righrs for Irrigation 4-5 (1936).

${ }^{20}$ See Charles H. Shinn, Mining Camps, A Study in American Frontier Government it-35 (1948); Colby, The Freedom of the Miner and Its Influence on Water Law, in Legal Essays IN Tribute To OrRIN KIP McMurRay 67-84 (1953).

${ }^{30}$ See 2 WIEL, op. cit. supra note 5, \$1039.

${ }^{31}$ See 2 id. \$ro4I. 
of such rights, when they exist at all, are few and brief. In the West, however, some constitutional and statutory provisions limit the extent and operation of these rights or abrogate them completely. ${ }^{32}$

The appropriation doctrine, although it is both statutory and judicial, was created by neither legislation nor court decision. It was first based on custom, which, in the absence of legislation, the courts recognized as controlling. ${ }^{33}$ Generally throughout the West, the earliest statutes essentially codified prevailing local customs, rules, and regulations that had grown up in the appropriation centers. ${ }^{\mathbf{3 4}}$ Later, as development progressed and complications ensued, there came the enactment of longer, more detailed, and more comprehensive statutes, supplemented by hundreds of high court decisions as well as constitutional provisions. ${ }^{35}$

\section{Property Rights in Water}

The water right is real property. The riparian right is said to be not merely an easement or appurtenance, but part and parcel of the land. The appropriative right generally becomes an appurtenance to the land in connection with which the right is completed..$^{36}$ These attachments to land, however, are not necessarily permanent.

Except as noted below, ownership of a water right does not constitute ownership of the particles or corpus of the water while in the natural source of supply. The owner's right is to take the water from the natural source and to put it to use. ${ }^{37}$ The common-law doctrine of percolating water rights, however, provides an exception. Its essential feature is exclusive ownership of the water while it is in one's land..$^{38}$ But this so-called "ownership," as has been noted, is one to which the law affords no right of protection against depletion by the heavy pumping of a neighbor.

\section{Waters and Lands}

a. Waters to which rights attach. Waters to which rights of use attach are chiefly those of natural sources. But a watercourse that was originally constructed artificially, if subjected to long-continued use and acquiescence by interested persons who have come to depend on it, may, by reason of these circumstances, be held to have acquired all the attributes of a natural watercourse and to be subject to all the rights that apply thereto. $^{39}$ The general rule also is that both riparian and appropriative rights may attach to navigable as well as nonnavigable waters, but always subject to the public easement for navigation. ${ }^{40}$

b. Riparian and overlying lands. The water right that pertains to a tract of riparian or overlying land arises by operation of law because the surface stream flows

\footnotetext{
s2 See Nat'L Reclamation Ass'N, op. cit. supra note 25, at 31-44.

${ }^{33}$ See, e.g., Jennison v. Kirk, 98 U. S. $453,457-58$ (1879).

34 See Harding, op. cit. supra note 28, at 22.

${ }^{35}$ See Nat'l Reclamation Ass'n, op. cit. stipra note 25 , at $3 \mathrm{I}-44$.

${ }^{\text {so }}$ See I WIEL, op. cit. supra note 5, \$\$550-5I, 711; 2 id., \$\$1103-04.

${ }^{37}$ See I id., \$I8.

${ }^{39}$ See Hutchins, op. cit. supra note 5, at 18.

so See Nat'l Resources Planning Board, op. cit. stipra note 19, at 12.
} 
across it or along its border, or because the waters of a subterranean stream or percolating supply move through the particles of its substrata. Physical contact of land and water is an essential factor. In addition, the weight of authority-at least in the West-is to the effect that a riparian tract cannot exceed the original grant from the government nor extend beyond the boundary of the watershed of the stream to which the tract is contiguous. Moreover, conveyance of any part of the original tract that does not touch the stream (unless otherwise provided in the deed of conveyance) may result in the loss of riparian rights with respect to that part. ${ }^{41}$ There are many questionable cases, however, owing to the fact that the courts in some states appear not precisely to have determined what is to be regarded as riparian land.

c. Lands associated with appropriative rights. The appropriative right may be acquired and utilized in connection with land, whether or not the land is contiguous to the source of supply. In most western jurisdictions, water may be appropriated for use outside the watershed in which it naturally flows. This is subject to the condition that no injury be inflicted thereby upon existing rights in the original watershed. And in some instances, the watersheds of origin have preferential rights, even though they are not yet exercised. ${ }^{42}$ The majority view also is that the appropriator need not be the owner of the land in connection with which he proposes to appropriate water, but must at least be in lawful possession-such as an entryman on public land or a lessee of private land. ${ }^{43}$

\section{Methods of Acquiring Water Rights}

The riparian right of a proprietor of privately-owned riparian land accrues when the land title passes to private ownership-when it is first acquired by grant from the sovereign power or by patent under general land laws. There is no formality in acquiring the water right other than acquisition of title to the land. Rights to the use of percolating waters arising out of ownership of overlying land are acquired in the same way. ${ }^{44}$

Each of the seventeen western states, however, has a statutory procedure under which water of watercourses may be appropriated. Of these states, eleven also have ground-water appropriation statutes. Most of the procedures contemplate applications to state officials to appropriate water, permits, and licenses or certificates when the appropriation is complete. With a few exceptions, the statutory procedures are held or at least considered to be the exclusive means by which an appropriation of water can be made. ${ }^{45}$

\section{Relative Rights of Water Users}

a. Rights based on landownership. Where the English doctrine as to percolating water prevails, each landowner holds an exclusive right that is independent of all

11 See Hutchins, op. cit. supra note 5 , at 40.

t2 See Nat'l Resources Planning Board, op. cit. supra note $x 9$, at 14 -15. See also note 78 infra and accompanying text.

${ }^{13}$ See $i d$. at 12.

" See I Wrel, op. cit. stipra note $5, \S 711 ; 2$ id., $\$ 1103$.

${ }^{28}$ See Hutchins, sipra note 20 , at 170 . 
the others. Under the American rule, however, the use of water by each landowner must bear some reasonable relationship to the use of the overlying land. Export of the water from the area for commercial purposes or waste of the water to the injury of others is not a reasonable use; otherwise, the specific criteria governing these relationships have not been well developed.

Rights of riparian proprietors and of overlying owners based on correlative principles are coequal. In time of water shortage, each landowner is entitled to a reasonable share of the common supply. No proprietor acquires an advantage over others solely because he uses the water first; so far as they are concerned, he may begin his reasonable use at pleasure and may suspend his use at any time and resume it at will. ${ }^{46}$

b. Appropriative rights. Each appropriator is entitled to the use of whatever water he needs, up to the limit of the terms of his right, out of whatever surplus water there may be in the supply above the aggregate quantities necessary to satisfy all rights prior to his own, before any water may be claimed by appropriators subsequent to him in time. This is true regardless of the relative locations of headgates on the stream. ${ }^{47}$

\section{Quantity of Water}

a. Rights based on landownership. These rights normally do not relate to specific quantities of water. The riparian or correlative overlying owner is entitled to a reasonable share of the aggregate quantity of water available for the requirements of all owners at a particular time. In the event of shortage, apportionment of the supply may be made by court order. Decrees of apportionment take account of the then existing needs of the landowners, usually on a proportional basis, and remain in effect as long as the conditions remain substantially the same as at the time of apportionment. But a new or a modified apportionment may be made whenever the conditions justify it. The law has not been clearly developed in such respects in some riparian states that follow a doctrine of reasonable use, while in some states, certain elements of the 'natural flow' rule may still apply. ${ }^{48}$

In California, riparian or correlative proprietors are held to be entitled to all the water of a particular supply that they can put to reasonable beneficial use on their lands, but to no more; and appropriators may take the surplus. In case of controversy, the riparian or overlying owners must first prove the quantities of water they need, whereupon the burden is shifted to the appropriators to prove the existence of a surplus in the supply to which their rights may attach. Quantitative limitations on the riparian and overlying rights then become specific. ${ }^{40}$

b. Appropriative rights. Appropriative rights do relate to specific quantities of water. The element of priority negatives any obligation on the part of the appropri-

\footnotetext{
${ }^{10}$ See $i d$. at $160-65$. See also Welis A. Hutchins, The California Law of Water Ruguts 436-4 , 446-54 (1956).

${ }^{\$ 7}$ See 2 KINNEY, op. cit. supra note $5, \$ \$ 782-85$.

${ }^{\iota s}$ See I WIEL, op. cit. supra note $5, \$ \$ 751-53$.

${ }^{10}$ See Hutchins, op. cit. stipra note 46 , at $226,441-44$.
} 
ator to share with other appropriators, in proportion to their respective reasonable needs, a water supply that is not enough to fill their aggregate quantitative requirements. But at no time is the appropriator entitled to divert and use more water than he then needs, even though the quantity he needs may be much less than that to which his right relates. Whatever part of the water covered by an appropriative right is not needed is available for other appropriators in the order of their respective priorities. 50

\section{Purpose of Use of Water}

a. Beneficial uses. Generally, any use of water that is beneficial may be made in the exercise of a water right.

b. Preferences in use of water. Riparian uses of water are divided into natural or ordinary uses, and artificial or extraordinary uses. Natural uses are those necessary to maintain the lives of occupants of the riparian land; artificial uses are commercial or business uses, such as irrigation, industrial, and development of power. Preference is accorded to natural uses in time of water shortage, and to upstream natural uses over those downsteam.

Notwithstanding the basic feature of priority, the constitutions and statutes of a few western states provide, in effect, that when the water supply is not enough for all appropriators, domestic users shall have the first preference and irrigators the second. In some cases, compensation is required. Regardless of the wording of the provision, however, no supreme court decision has come to attention in which such a preference has been enforced as against the holder of a right prior in time without payment of compensation.

Preferences in acquiring appropriative rights are expressed in some statutes. Some preferences apply in the granting of permits, such as between conflicting applications that are pending before the state administrator at the same time; or in imposing conditions in a permit, subordinating it to subsequent permits for preferred uses. The purpose of others is to provide for the condemnation of inferior rights for superior purposes. And in still other cases, municipalities are granted certain preferences in appropriating water. ${ }^{52}$

\section{Exercise of Water Rights}

a. Handling of water. Water may be diverted at any convenient point on riparian land. Under some circumstances, it may even be diverted upstream, so long as the rights of other proprietors are not impaired. The unused portion of diverted water must be returned to the stream above the lower boundary of the riparian land, or at least above the diversions of downstream owners. ${ }^{53}$ In the case of an appropriator, however, the point of diversion is an element of his water right; it is there that the right attaches to the stream. ${ }^{54}$ And any unused water so diverted must be promptly returned to the stream. ${ }^{50}$

\footnotetext{
${ }^{20}$ See 2 KINNEY, op. cit. supra note $5, \$ \$ 782-85 . \quad 51$ See I WIEL, op. cit. stupra note $5, \S \S 740-44$.

${ }^{22}$ See Hutchins, op. cit. supra note 5, at 337-58. $\quad{ }^{53}$ See $\mathrm{r}$ WIEL, op. cit. supra note $5, \$ \$ 754-55$.

st Sce Nat'l Resources Planning Board, op. cit. supra note 19, at 10.

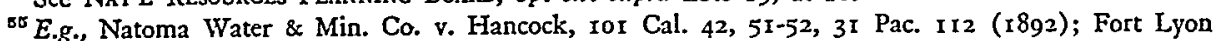


Methods of diverting, conveying, and using water must be reasonably efficient. In current water-law philosophies, unnecessary waste of water is within neither the riparian nor the appropriative right; but in applying the requirement of reasonable efficiency to the circumstances of a given case, the custom of the country is an important influence. ${ }^{56}$

The riparian or overlying water right may be exercised at any time of the year. The appropriative right, on the contrary, relates to a specific period. This may be the entire year, as in some parts of the American Southwest, or it may be for certain months only. ${ }^{57}$

b. Changes in exercise. Water rights of lands based on contiguity to the source of water supply do not, of themselves, contain limitations on the right of the proprietor to change his points of diversion and return of the water from place to place within his riparian tract, or to change the place of use from one part of the tract to another, or to change the purpose of use of the water. Presumably such changes may be made so long as the new use or method of use is within the scope of the water right. ${ }^{58}$

In most western states, too, an appropriator may change the location of his point of diversion, place of use, or purpose of use, provided the rights of others are not thereby impaired. Some statutes contain procedure by which the change may be formally made and recorded. In some states however, such changes may be made only with permisison of the state engineer, after petition and hearing of objections. ${ }^{60}$

\section{Loss of Water Rights}

a. Abandonment. Appropriative rights may be lost by abandonment, when the intent of the holder to give up his right is accompanied by actual relinquishment. No time element is involved. When intent and relinquishment concur, abandonment takes place instantly. ${ }^{60}$ Riparian and other rights that inhere in ownership of land and that are part and parcel of the land, on the other hand, are not subject to abandonment. Such rights are not created by use, and in the absence of prescription, they are not lost by disuse. ${ }^{61}$

b. Statutory forfeiture. Statutes of many western states provide that failure to make use of an appropriative right for a specified period of years results in forfeiture of the right. Intent is not material; the essential elements are nonuse and lapse of

Canal Co. v. Chew, 33 Colo. 392, 399-400, 81 Pac. 37 (1905); Gunnison Irr. Co. v. Gunnison Highland Canal Co., 52 Utah 347, 357, r74 Pac. 852 (r918); Anderson v. Bassman, 140 Fed. 14, 29 (N.D. Cal. I905) (decree restricting upstream claimants, whether riparian or nonriparian owners, from using water from the stream where no provision was made for returning the surplus watcr thereto).

${ }^{50}$ See Hutchiss, op. cit. supra note 5, at 306-09, 316-20.

${ }^{87}$ See Nat'l Planning Resources Board, op. cit. stipra note 19, at yo.

${ }^{88}$ See I KINNEY, op. cit. stipra note 5, \$521.

${ }^{50}$ See Nat'l Planning Resources Board, op. cit. sitpra note i9, at 15-16.

${ }^{\circ 0}$ See I WIEL, op. cit. supra note 5, $\$ 567-69 ; 2$ KINNEY, op. cit. supra note 5, \$\$1 100-05.

os See I Wied, op. cit. supra note 5, $\$ 86 \mathrm{I}$; Nat'l Resourcts Planning BoArd, op. cit. supra note 19, at 17 . 
time. $^{62}$ The forfeiture statutes do not, however, apply to riparian and correlative percolating water rights. ${ }^{63}$

c. Prescription. Water rights of most types are subject to loss by adverse possession and use, for the period of time prescribed by the statute of limitation of actions to recover real property, when accompanied by all the elements necessary to establish prescription. $^{64}$ Losses by prescription have been adjudicated with respect to riparian rights, correlative rights of overlying landowners, and appropriative rights. ${ }^{65}$

d. Estoppel. Equitable estoppel may occasion the loss of an appropriative right. ${ }^{66}$ Under some circumstances, a riparian owner, too, can be estopped from objecting to an appropriative diversion that deprives him of the use of water to which he would otherwise be entitled. ${ }^{67}$

e. Other ways of severing riparian rights from land. In California, where cases of severance of riparian rights from riparian land have been most extensively litigated, the following principles have been declared: ${ }^{68}$

(I) A riparian owner whose land is cut off by avulsion from contiguity to the stream thereby loses his riparian right, unless he restores the stream to its original channel within a reasonable time and without trespassing on the lands of others.

(2) In the subdivision of a riparian tract, parcels, lying back from the stream which are thereby cut off from contact lose their riparian rights, unless the intention to preserve them is mentioned specifically in the deeds or is necessarily implied by the circumstances. If the riparian right of a detached parcel is once lost, it can never be regained, even if the parcel is later united in ownership with lands contiguous to the stream.

(3) In a partition of riparian land, riparian rights are preserved in all of the subdivided parcels, whether or not severed from contact with the stream, unless the decree of partition provides otherwise.

(4) A riparian owner who sells his land may reserve the riparian right by a clause in the deed of conveyance.

(5) A riparian owner may grant his riparian right to another person who proposes to divert the water to nonriparian land. Such a grant is not made in the exercise of his riparian right, and it does not transfer the riparian right to nonriparian land. Its only effect is to waive the right of the grantor to object to the grantee's diversion.

\footnotetext{
${ }^{02}$ See I WIEL, op. cit. supra note $5, \$ \$ 574-78 ; 2$ KINNEY, op, cit. supra note 5, §\$III 8-20; HuTchins, op. cit. stipra note 5, at 392-97; NAT'L Resources Planning BoARd, op. cit. supra note I9, at 17-18.

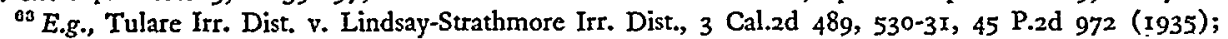
Freeland v. Peltier, 44 S.W.2d 404, 408 (Tcx. Civ. App. 193I); Pasadena v. Alhambra, 33 Cal.2d 908, 933-34, 207 P.2d I7 (1949).

of Sce Nat'l Resources Planning Bonrd, op. cit. supra note 19, at 18-19. See also Craig, Prescriptive Water Rights in California and the Necessity for a Valid Statutory Appropriation, 42 Calif. L. REv. 219 (1954).

${ }^{o r}$ Sec I WIEL, op. cit. stipra note $5, \$ \$ 579,863$, 1170 . See also Pasadena v. Alhambra, 33 Cal.2d 908, 1)26-33, 207 P.2d I7 (1949).

o See I WIEL, op. cit. supra note 5, $\$ \$ 593-95$.

${ }^{77}$ See Hutchiss, op. cit. silpra note 46 , at 193-94.

${ }^{\circ B}$ Sec id. at $189-96$.
} 
The contract is binding on the parties and their successors but not on other riparian owners who do not consent to the transaction.

(6) The riparian right may be condemned for public use under the laws relating to eminent domain.

\section{Permit Systems}

In some eastern states, legislation requires a permit from a state agency to take water for irrigation or other purposes from a watercourse; and in a few states, from a ground-water source. It is doubtful whether, in most such states, these permits create any substantial property rights. ${ }^{60}$ Although they probably have little effect on riparian rights, they may provide some administrative restraint upon the exercise of these rights, and they do provide a record of use that should be extremely useful in considering water rights legislation and administration in the future.

\section{Conflicts and Their Adjustment}

\section{Riparian and Appropriative Rights ${ }^{\mathbf{7 0}}$}

The conflict between appropriative and riparian rights has been significant only in the seventeen western states. There, the century-old impasse has been settled in some jurisdictions, at least so far as basic principles go, but it still persists in others.

Individual conflicts have stemmed principally from the asserted right of the riparian owner to have the stream flow down to his land. Although the "natural flow" theory of the common law had been so modified, where irrigation was important, as to allow each riparian owner to make a reasonable use of the water on his riparian land, even though the result was to lessen the flow to downstream proprietors, there was nothing in the riparian doctrine that required the latter to submit to upstream diversions to nonriparian lands. On the same stream, then, there have been riparian landowners who have claimed that their water rights entitled them to the full flow of the stream as against nonriparian diversions, whether or not the riparians had ever used the water or presently intended to do so; and appropriators who have claimed that priority of diversion and use of water should govern, whether the use be made on riparian or nonriparian land. Conflicts also have resulted in some areas from claims by riparians of the right to use water wastefully or to withhold use without losing the right. And in still others, they have arisen simply from competition between early and late comers for the use of water supplies not sufficient for all.

Considering the West as a whole, the trend has been toward bringing the operation of the riparian doctrine-where it is recognized-more into line with standards of use generally applicable to appropriators. This has been accomplished by substantially modifying the common-law right for the purpose of reducing or eliminating its obstructive aspects. At present, a riparian owner has no more license to waste water than has an appropriator; and the appropriator never has had the right to do that, although in practice, he may, in many cases, actually have diverted more than

\footnotetext{
${ }^{80}$ See Ellis, supra note 15 , at 238.

${ }^{70}$ See generally, Hutchins, History of the Conflict Between Riparian and Appropriative Rights in the Western States, in Proceedings of the Water Law Conferences, University op Texas io6 (1954).
} 
he put to beneficial use. In a few of the western jurisdictions, however, the interrelationships of riparian and appropriative claimants have not yet been definitely established.

a. Nature of adjustments. The riparian-appropriative conflict has effectively been settled in eight of the seventeen western states by repudiating the riparian doctrine in toto. In some of these jurisdictions, the doctrine never had been recognized. In a few, its status was in question during the early years of water development. And in one state, the supreme court actually recognized the riparian doctrine for a time and then repudiated it.

In the dual-system states of the West-the six lying on the Iooth meridian and the three bordering the Pacific Ocean, some portions of which are generally humid and other portions generally arid or semiarid-conflicts have resulted in retaining the riparian doctrine but modifying its principles. The extent of modification of the common-law doctrine and the resulting effectiveness of the appropriative principle when opposed, in a particular area, by the riparian vary considerably. Some examples are:

(I) As the result of legislation and court decisions, the riparian doctrine has been reduced to little more than a legal fiction and to minor importance in the economy of the state.

(2) The riparian owner must put the water to reasonable use in order to hold it as against the claim of an appropriator.

(3) The riparian doctrine in its reasonable-use phase is fundamental, but superimposed upon it is a system of appropriative rights that relate to the surplus waters above those to which riparian rights attach. With respect to the full quantities of water necessary to supply the riparians, their rights are paramount. But equally paramount to the claims of riparian owners are appropriative rights with respect to the surplus.

b. Unused riparian rights. A major difficulty in these adjustments is the matter of unused riparian rights. In as much as in the strict application of the riparian doctrine the water right is neither gained by use nor lost by disuse, future use stands as high as present use and is equally entitled to protection of the law against impairment by appropriative diversions. This right reaches into the indefinite future; there is no time limitation whatsoever.

In jurisdictions in which the courts hold to the sanctity of the unused right, statutory attempts to provide for their forfeiture have not been tolerated. California is one of these states. There, in order to preserve the unused right from loss by adverse use, the riparian owner may obtain a declaratory decree against a person whose diversion for nonriparian purposes threatens to ripen, if continued, into a prescriptive right. The effect of this declaratory judgment and decree is to enjoin the adverse party from diverting the water at any time the riparian wishes to use it and from claiming a right by adverse use as against the latter.

The question of unused riparian rights has been met in some other states 
by requiring the riparian owner to begin making beneficial use of the water within a certain time fixed by statute, or, in the event the water is wanted by an appropriator, either to begin use within a reasonable time or to allow the appropriative right to take precedence. Whe ther the courts have gone along with legislative attempts to do this has depended upon the extent to which they considered their former declarations as to future use stare decisis.

\section{Ground Water Rights}

2. Correlative overlying and appropriative rights. Conflicts between these rights have been confined to much smaller areas and to shorter times than have the historic riparian-appropriative conflicts. In California, where they have had the attention of the courts in a considerable number of cases, the interrelationships are the same as those of riparian and appropriative rights. Basically, the rights of overlying owners are paramount, and appropriators for nonoverlying uses may take the surplus. And an overlying owner may have his right of future use protected by obtaining a declaratory judgment and decree. ${ }^{11}$

b. Absolute ownership and appropriative rights. The conflict between a right of absolute ownership of percolating water and a right of appropriation in a stream with which the percolating water is physically connected is irreconcilable. There is no present legal basis for adjusting such conflicting rights so long as the right of an overlying landowner to the ground water in his land is held to be absolute.

\section{E. Comparative Evaluation}

To the extent that water development is carried on by individuals and small groups, the question of what basic doctrine shall prevail comes to the fore. The following comparisons are based on western experience with the appropriation and riparian doctrines. This experience cannot, it should be noted, be carried directly to eastern problems without extensive study and probably some trial and error.

\section{Riparian Doctrine}

a. Some advantages. By contrast with the appropriator who holds a junior or late-season right, the riparian landowner is assured of at least some water whenever it is available.

In its common-law form, the riparian right is not lost solely by disuse; although in some western jurisdictions the right must be exercised if the landowner is to hold it. Where this right of future use is recognized, the riparian right may be safeguarded by declaratory decree against loss by prescription on the part of an appropriator. This is an obvious advantage from the standpoint of the riparian owner. From the standpoint of "unfreezing" unused water rights so that the water may be made available for use, however, it is a material disadvantage.

In the West, the trend is to hold the riparian owner to reasonable use as against an appropriator as well as against other riparian proprietors.

Although the right of a riparian owner encompasses the use of the water only

${ }^{71}$ See Hutchins, op. cil. supra note 46 , at $441-46,454-59,493-94,498,500$. 
on his riparian land, he can purportedly sell his riparian right to a nonriparian owner, the effect of which (in California) is simply to estop him from objecting to the latter's diversion.

The riparian doctrine is better suited to a situation in which the demand for the water does not exceed the supply and large investments are not required to develop water supplies.

b. Some disadvantages. Where the right of future use is recognized, the unused riparian right can be held indefinitely without forfeiture, which means that riparian owners who have been making use of the water may have to forego some of their accustomed use when the previous nonusers elect to demand their shares.

The riparian doctrine tends to "freeze" a variable quantity of water to a specific tract of land. By contract, however, at least in California, the riparian owner can ostensibly sell his riparian right to a nonriparian and thus estop himself from objecting to the latter's diversion.

In its common-law form, the riparian right contemplated forebay storage only. In California and Washington, the courts have held that the riparian right does not cover seasonal storage of water; such storage may be accomplished only under appropriative rights.

Originally in California, where most of the disputes between riparian owners and appropriators have been litigated, the courts held that the riparian owner was not limited to any measure of reasonableness as against an appropriator. Now, as a result of a constitutional amendment and its favorable interpretation by the supreme court of the state, the riparian is limited to reasonableness as against appropriators as well as against other riparians.

The contribution of the riparian doctrine to the building of western agriculture has been much less than that of the appropriation doctrine. The riparian doctrine apparently was satisfactory in eastern states until recent demands for water raised questions of adequate supplies.

\section{Appropriation Doctrine}

a. Some advantages. This doctrine assures the holder of the water right of his full appropriative supply of water, in order of priority, whenever the water is available. Hence, early priorities have reasonable assurance of a water supply each year. Thus, it enables development to be predicated on a reasonably assured water supply. Much of this advantage would be lost if water could be appropriated for only a period of years, not in perpetuity, in an area in which irrigation is necessary to agriculture.

Although in early days there were rendered some excessive decrees that still give trouble, the appropriation doctrine always has been limited, in theory, to beneficial use. It has come to be further limited to economical or reasonable use as against other appropriators. This does not mean a sharing of the water by senior and junior appropriators in time of shortage; it means simply that the appropriators shall divert, convey, and use the water not only without unnecessary waste, but with as high a 
degree of efficiency as is consistent with the general economy and actual practices of the community.

Appropriation statutes can, and many of them do, provide restrictions on the right to appropriate water in the interest of the public welfare. Such restrictions have not yet included criteria based on character of the land; but there is no reason why the state could not provide that an application to appropriate water shall be rejected where the land proposed to be irrigated is poor, thus withholding the water in favor of later applicants for use on better land. The state grants the right to appropriate water, and it can certainly regulate the method of appropriation. This would be a proper exercise of its police power.

Water can be appropriated for storage for beneficial use, whether the storage be temporary or seasonal.

The prevalence of provisions in the western statutes, and approval of the principle by the courts, for changes in exercise of water rights-point of diversion, place of use, and purpose of use-where no injury is inflicted on others, allows a considerable measure of flexibility in the application of this doctrine.

The appropriative right can be lost by abandonment or statutory forfeiture. An essential feature of the appropriative right is that it is gained by use and may be lost by disuse.

On the whole, the appropriation doctrine has contributed materially to the agricultural development of the West, where the acreage of good land has exceeded the quantity of water with which to irrigate it.

b. Some disadvantages. .Holders of late priorities probably have little assurance of water supply in most seasons, and the very late ones have no assurance except in years of extremely heavy runoff. Under the essential philosophy of the doctrine of prior appropriation, diversions under later priorities are reduced or cut off entirely when the supply is less than sufficient to fill the requirements of all those earlier in point of time.

The appropriation doctrine tends to "freeze" a specific quantity of water to a specific tract of land. The provisions for transferring the use of the water to other purposes or to other lands tend to lessen this disadvantage; but there is no provision in the law, aside from condemnation, for requiring an appropriator to accede to a change of the place of use of his appropriated water from one tract to another so long as his right is in good standing. In other words, there is a large measure of inflexibility with respect to a continuously-used appropriative right, even though the water might be put to better use elsewhere.

In areas in which both riparian and appropriative rights are recognized, a riparian owner may prevent the ripening of a prescriptive right in favor of an appropriator by obtaining a declaratory decree against him.

\section{Summary.}

This enumeration of the asserted advantages and disadvantages of the riparian 
and appropriation doctrines, as they influence individual effort in developing water resources, seems to indicate the need for modification in both doctrines in the future to meet changing economic conditions. In the eastern states, there is a strong movement toward modification of the riparian doctrine to foster more development of water resources by individuals and small groups. The purpose is to assure the person who develops a water supply a reasonable opportunity to recover the benefits from his efforts. This movement to modify the riparian system might be characterized as a move toward certain elements of the appropriation doctrine, but it will probably result in something quite different from the western appropriation doctrine.

Because of the nature of the remaining opportunities in surface water resources, our greatest future development will come from group enterprises and large-scale public projects encompassing entire river basins. The relation of the above-outlined water rights doctrines to such projects will, accordingly, be explored in the next part.

\section{III}

\section{Implications for River Basin Development}

\section{A. By Whom Is the Development to Be Made?}

The implications of the various water rights doctrines for river basin development will depend, to some extent, on which agency or agencies participate in the undertaking. Will the development be made exclusively by federal, state, district, or individual effort, or by some combination or combinations of these?

Let us assume, first, that the federal government will develop the river basin.

The powers of the federal government are limited to those delegated by the Constitution. Over the years, these delegated powers have been interpreted by the Supreme Court and extended by congressional action to provide a significant body of law and authority for water resources development as to navigation, flood control, irrigation, power, other public purposes, and related land uses. Under the commerce power, ${ }^{72}$ for example, Congress has jurisdiction over all navigable waters and nonnavigable tributaries as related to navigable capacity of the navigable waterways. And not only has the Supreme Court outlined the authority available to carry out this specific function, but it has also indicated that in the exercise of the commerce authority, there is no constitutional impediment to Congress in comprehensive development of navigable rivers and their watersheds: $:^{73}$

It is for Congress alone to decide whether a particular project, by itself or as part of a more comprehensive scheme, will have such a beneficial effect on the arteries of interstate commerce as to warrant it. That determination is legislative in character.

In section eight of the Reclamation Act of $1902,{ }^{74}$ based on the property clause, ${ }^{76}$ which vests in Congress the authority to control the use of federal public lands, how-

\footnotetext{
${ }^{72}$ U.S. CONST. art. I, $\$ 8$, cl. 3 .

73 President's Water Resources Policy Comm'n, Report 23 (I950).

7432 StAT. 390 (I902), 43 U.S.C. $\$_{3} 83$ (I952).

${ }^{75}$ U.S. Const. art. IV, $\$ 3$, cl. 2.
} 
ever, the Secretary of the Interior is directed to proceed, in carrying out the terms of that act, in conformity with state laws relating to the control, appropriation, use, or distribution of water used in irrigation. There is now a vigorous movement to have Congress apply that same principle to all federal agencies in dealing with water where rights of use may be affected.

Let us assume, second, that the state will develop the river basin, as California proposes to do with respect to the Feather River.

In such instances, the state files on the unappropriated water in the basin, stores the water and conveys it to the places of use, and delivers it to consumers through the media of organizations. The state is the formal appropriator, as is the Bureau of Reclamation with respect to federal reclamation projects, and the state contracts with intermediate organizations for delivery to the water users; but some courts say that these users are the actual appropriators, even though title to the right is held by the agency that makes the formal appropriation. ${ }^{76}$

Planning and development in river basins, however, will probably be carried out by combined efforts. The Advisory Committee on Water Resources Policy suggests that to achieve the maximum beneficial use of water resources, planning for their use must be participated in by the interested federal agencies, the states, local governments, and private citizens. ${ }^{77}$ Full development will require the resources and powers of both state and federal governments.

Under our system of constitutional government, it is fundamental that rights of private property must be respected. Persons may not be deprived of their property without due process of law, nor may private property be taken for public use without just compensation. But by exercising the power of eminent domain, a governmental or public agency, when adequately empowered and financed, may take established rights of property-in this case, water rights-and may reshuffle the water and its uses and users through the medium of contractual relationships.

\section{B. What Are the Existing Water Rights Doctrines in the River Basin?}

In all states in which planned river basin development will take place, some form or forms of water rights doctrine already exist. In the West, this may be solely the appropriation doctrine for surface streams, or it may be appropriation and riparian combined; for percolating ground water, it may be appropriation, or it may be some principle that rests on ownership of overlying land. In the east, this will generally be the riparian doctrine as to surface water, and either the doctrine of absolute ownership or that of reasonable use with respect to percolating ground water.

${ }^{70}$ Ickes v. Fox, 300 U.S. 82, 93-95 (1937); Nebraska v. Wyoming, 325 U.S. 589, 612-15 (1945); Murphy v. Kerr, 296 Fed. 536, 544-45 (D. N. M. 1923), aff'd, 5 F.2d 908 (8th Cir. 1925); Prosole v. Steamboat Canal Co., 37 Nev. 154, 159, x62-65, I40 Pac. 720, I44 Pac. 744 (1914); Whiting v. Lyman Water Co., 59 Ariz. 121, 124, 124 P.2d 316 (1942). Contra, Farmers' Cooperative Ditch Co. v. Riverside Irr. Dist., I4 Idaho 450, 457-59, 94 Pac. 76x (1908); In re Walla Walla River, I 41 Ore. 492, 496.98, 16 P.2d 939 (1932). Neither the ditch company alone nor the users alone are appropriators in the strict sense of that term. Jefferson County v. Rocky Mountain Water Co., ro2 Colo. 351, 356, 79 P.2d 373 (1938). See discussion in 2 WIEL, op. cit. supra note $5, \$ \$ 1338-47$.

77 Presidential Advisory Comm. on Water Resources Policy, op. cit. supta note $x$, at 14. 
In jurisdictions in which the riparian doctrine is firmly established, there may be a question of superimposing some form of the appropriative principle on the underlying riparian system, because the riparian doctrine, in its original commonlaw form, is not alone adequate for river basin development in any area in which the available water supply falls short of the quantity needed for all demanded uses. In these jurisdictions, the riparian right probably is not lost by mere failure to exercise it, so that an unused right may be put to use at any time in the future, regardless of demands of appropriators. This presents a serious problem; but if, in a given state, the court decisions with respect to the vesting of riparian rights are few and of little practical effect, the changeover to a predominantly appropriative system might be less difficult.

In states in which the riparian doctrine has been repudiated and rights to the use of water may be obtained only by appropriation, riparian problems are a thing of the past-if they ever existed-and a major problem is and will be to use the appropriative principle to its best advantage and to make needed modifications to conform to large area development.

Where the riparian and appropriation doctrines exist concurrently, their adjustment necessarily poses substantial problems. This is the case in the two largest states, where adjustments between these basic doctrines have been made, are being made, and doubtless will continue to be made.

\section{Water Rights Doctrines in Relation to Continuing Large-Scale Development}

The trend in both the West and the East is toward large-scale development of surface water supplies. In many areas, the smaller opportunities are largely exhausted, and group organizations and public agencies have been and are being more and more employed for the purpose of storing water and conveying it considerable distances to the places of use. An extreme example: The Feather River Project in California proposes to take water from the northern Sierra Nevada and convey it almost to the Mexican border-a distance of hundreds of miles, down the Sacramento Valley, up the San Joaquin Valley, over a mountain range, and thence into southern California. The principal water rights problem there is created by the "areas of origin" statute which requires that areas in which water originates shall not be deprived of the full quantity they need by reason of any state or federal project. ${ }^{78}$ The State Department of Water Resources is directed to file on all unappropriated water needed for state projects. When the "areas of origin" question is settled-by some arrangement that will safeguard not only the valid claims of areas of origin, but also the equities of areas to which the excess water is exported-a major problem in such projects will be that of dealing with users of water on the basis of contractual relationships, rather than individual water rights.

In Nebraska, too, an issue arose as to whether the state should permit the

${ }^{78}$ See Cal. Water Code ANN. $\$ \$ 10500,10504,10505$ (West 1956) (water supplies of counties of

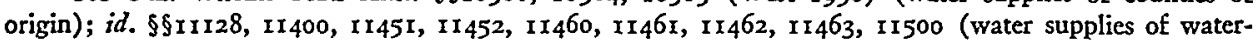
sheds or areas of origin). 
diversion and use of stored water to irrigate lands outside the basin from which the water was originally taken when the Central Nebraska Public Power and Irrigation District proposed to take some 600,000 acre-feet of water annually from the Platte River and use about sixty per cent of it outside the Platte River basin in the Republican River basin. The Department of Roads and Irrigation granted the necessary water allotments, but this action was appealed by both appropriators and riparians in the Platte Valley. After reviewing the legislative history and the impact on the economy of the Platte Valley, the Nebraska Supreme Court overruled the Department of Roads and Irrigation and declared the applications of the District to be revoked. ${ }^{79}$ Several bills have since been introduced in the state legislature to authorize transwatershed diversion, but none has passed, and the laws of Nebraska, as interpreted by the state supreme court, now forbid transwatershed diversion. ${ }^{80}$ This provision has direct impact on river basin development. Not only did the Central Nebraska Public Power and Irrigation District have to confine its water use development activities to the Platte River basin, but other proposed transwatershed diversions, as proposed by the Bureau of Reclamation, could not be undertaken. River basin development plans have, accordingly, been redirected toward the utilization of water resources within the watershed of origin.

Several other problem situations also arise in connection with large-scale development under the riparian system. The most commonly discussed is that faced by a group enterprise in developing a water supply for irrigation when it is economically desirable to store water and use it on lands not contiguous to the stream. Similarly, under the riparian doctrine, particularly as to nonnavigable watercourses, a city often does not have authority, solely as riparian owner, to transport water great distances for its use. It may, however, acquire needed rights through such measures as purchase, condemnation, and prescription. And in another situation, large-scale development by state, or more often by federal, agencies results in the almost complete elimination of private riparian rights. This is true where reservoirs are built to develop fully the power potential of a stream. Lands are purchased or condemned for reservoir purposes, and access to the reservoir is by permission of the developing agency. Between the lowest dam and the backwater of the highest reservoir, the river may be completely controlled, and, unless specifically reserved, riparian rights are acquired by the agency. In case of navigable streams, it has been held that the federal government holds a navigation easement and does not need to pay for riparian water rights where the development is for navigational purposes. ${ }^{81}$ Any use of water from the

${ }^{70}$ Osterman v. Central Nebraska Public Power \& Irr. Dist., 131 Neb. 356, 268 N.W. 334 (1936). Nen. REv. STAT. \$46-206 (1943) provides that water diverted from a stream shall not be turned into any other stream unless the former excceds $x 00$ feet in width, in which case not more than 75 per cent of the regular flow shall be taken. Sec. 46-265 provides that unused water shall be returned to the stream from which taken, or to the Missouri River. These sections, said the supreme court in the Osterman case, as a practical matter, necessarily limit the location of canals to places within the watershed of the stream that is the source of water supply.

${ }^{80}$ Nebraska Legislative Counciz, Subcomarttee on Water Division, Final Report 25 (1944).

${ }^{81}$ See 3 President's Water Resources Poltcy Comm's, op. cit. supta note 73, at 25-29. 
reseivoir must be under contract with the developing agency. With such complete development, the end result of large-scale development under the riparian system is apparently no different from the end result under the appropriation doctrine.

It seems inevitable that as these large-scale and basin-wide developments progressnecessarily with the aid of public financing and with control by public agencies or large group organizations-the water rights of new users will be represented less and less by permits and certificates of appropriation issued by the state engineers, and more and more by water service contracts with organizations charged with the distribution of water to users-which organizations themselves may either have appropriated the water, acquired all the riparian rights, or contracted for water supplies from public agencies which are the formal appropriators.

\section{Coordination of Surface and Ground Water Rights}

An important feature of successful river basin development is the coordination of all rights to the use of interconnected water supplies, both surface and subterranean. If all rights of use are governed by the appropriation doctrine, correlation is made on the basis of priority of appropriation. An example is Colorado, where rights that pertain to a certain stream are subject to prior rights in ground waters that feed the stream, and vice versa. ${ }^{82}$

If part of the rights are riparian and part appropriative, however, as in California, coordination includes adjustment of the two conflicting principles and correlation of all rights on the basis of reasonable beneficial use. Coordination is legally possible in cases in which there is some give-and-take, such as between rights of prior appropriation and riparian rights that have been restricted to reasonable beneficial use against appropriators. It is not legally possible in a case in which owners of lands overlying percolating waters tributary to a surface stream are recognized by the courts as having absolute ownership of the percolating water. In such a case, these landowners may lawfully cut off the percolating water entirely for their own use before it gets out of their lands and enters the stream. Nor is coordination possible where percolating water in these lands, instead of being tributary to a stream, has escaped from it. In that case, those who hold rights in the stream may, in the exercise of such rights, cut off the escaping supply completely without recourse on the part of the overlying owners, no matter how long the latter may have been using the ground water. By hydrologic processes, the percolating water enters and leaves the substrata of the overlying owner. While the water is in his land, where this doctrine prevails, he has an absolute right to use it; before entering his land, or after leaving it, no right at all.

\section{E. Interstate Matters}

River basins do not respect state lines. A number of cases have arisen and have been decided with respect to rights to the use of water of interstate streams. In some

${ }^{82}$ Black v. Taylor, 128 Colo. $449,458-59,264$ P. 2d 502 (1953); Nevius v. Smith, 86 Colo. x78, I8183, 279 Pac. 44 (1929); Faden v. Hubbell, 93 Colo. 358, 368-69, 28 P. 2d 247 (r933); Safranek v. Limon, I23 Colo. $330,334-35,228$ P. 2d 975 (I95I). 
such cases, private parties only have been involved; most of these have been litigated in federal courts. Others have risen to the dignity of interstate suits, brought and decided in the United States Supreme Court, which has original jurisdiction of litigated controversies between states.

The United States Supreme Court has laid down broad principles that must govern its decisions in such cases. ${ }^{83}$ Each state across which, or along the borders of which, an interstate stream flows is entitled to an equitable apportionment of the benefits of the stream. There is no set formula for making such an apportionment. Of those cases that have been litigated in the West, no two are alike. The Supreme Court takes the view that a contest between states is to be settled "in the large and ample way that alone becomes the dignity of the litigants concerned." ${ }^{84}$ The wide range of physical and legal conditions and combinations of conditions in interstate river basins is reflected in the diverse ways in which the Supreme Court has handled this broad principle of equitable apportionment of benefits between states. ${ }^{85}$

In addition to litigation in the Supreme Court, apportionments of waters of various interstate streams have been made by compact, with the consent of Congress. ${ }^{80}$ The Supreme Court has recommended that this, rather than resort to the Court, be the medium of settlement, ${ }^{87}$ and it has held that whether an apportionment be made by compact or by decree of the Court, it is binding on the citizens of each state and on all water claimants. ${ }^{88}$

There are some state statutes with respect to the appropriation of water within one state for use in another. A few states make it difficult or impossible to divert water legally within their boundaries for conveyance across the state line for use in an adjoining state. Others have what are called reciprocal statutes-they permit such appropriations to be made, provided the sister state enacts similar legislation. ${ }^{89}$

\section{F. Resource Management Districts}

As the demand for water increases and we apply more conservation measures on our land, more management and water-control measures on our watersheds, and more dams and channel-control structures on our rivers, we will reach a point at which all sizable streams and rivers will be more or less regulated and managed, and the concept of "natural flow" will have little meaning. Water supplies will be man-

${ }^{83}$ See 3 President's Water Resources Policy Comm's, op. cit. supra note 73, at 58.

${ }^{84}$ Washington v. Oregon, 297 U.S. 517,529 (1936).

${ }^{85}$ Cf. Kansas v. Colorado, 206 U.S. 46, 95-114, II7 (1907); Wyoming v. Colorado, 259 U.S. 419, 464-71, 488-89, 496 (1922); Connecticut v. Massachusetts, 282 U.S. 660, 669-74 (1931); New Jersey v. New York, 283 U.S. 336, 342-48 (I93I); Washington v. Oregon, 297 U.S. 517, 522-30 (1936); Hinderlider v. La Plata River \& Cherry Creek Ditch Co., 304 U.S. 92, I01-11 (1938); Colorado v. Kansas, 320 U.S. $383,391-400$ (1943); Nebraska v. Wyoming, 325 U.S. 589, 617-27, 631-46 (1945).

${ }^{80}$ See 3 President's Water Resources Policy Comm'n, op. cit. stipra note 73, at 64 .

${ }^{87}$ See Colorado v. Kansas, 320 U.S. 383,392 (1943).

${ }^{88}$ Hinderlider v. La Plata River \& Cherry Creek Ditch Co., 304 U.S. 92, 106 (1938).

${ }^{80}$ See Hutchins, op. cit. supra note 5, at 403-07; Nat'l Resources Planning Bodrd, op. cit. supra note 19, at 19-21; Hutchins, op. cit. supra note 46, at 364-67; Wells A. Hutchins, Trie Nevada LAw of Water Rights 5I-54 (1955), The New Mexico LaW of Water Rights 38-42 (1955); The IDAHO LAW OF WATER RIGHTS $83-85$ (1956). 
aged, and the participation of water users in water-management decisions will become extremely important. This prospect suggests the need for strong, locally-controlled resource-management districts which might carry out the local phases of river basin development usually under agreement with the developing agency. Since "rights" to use will be directly affected by management of water supplies, the direct administration of individual water rights by a state agency will become complicated and difficult. In such situations, the state may find it desirable to call upon local public districts for assistance in administering the individual water rights concerned, so that administration of rights and management decisions affecting water supply can be closely integrated.

\section{IV}

\section{Conclusion}

It is apparent that much of the water rights doctrine of this nation was designed to cope with problems that arose from individual efforts to develop and use natural water supplies. Because of both physical and economic factors, however, it has become increasingly clear that individual enterprise in this field must be more effectively supplemented by group and public efforts. In the light of these changing conditions, a reappraisal of the effectiveness of existing water law doctrines is in order.

The several doctrines that govern rights to the use of water, some of which have been centuries in the making, are based on either landownership or prior appropriation. The former group comprises the riparian doctrine with respect to watercourses, and the English, American, and correlative doctrines with respect to percolating ground waters-all of which accord rights to the use of water to certain land solely because of the land's contiguity to the source of water supply. Under the appropriation doctrine, on the other hand, water rights that pertain either to watercourses or to percolating ground waters are acquired by those who first divert the water and put it to beneficial use. In some states in which opposing systems-such as riparian and appropriation-are recognized, adjustment of conflicts has occupied the attention of courts and legislatures for many decades, and important problems still await solution. Each of the doctrines has certain advantages and disadvantages, depending on the point of view adopted-for the interest of the individual water user and that of the public at large are not always identical.

As consumptive use of water has increased, extant water law doctrines have been reexamined. In some western states, landownership doctrines-both riparian and ground water-have been eliminated in favor of exclusive appropriation systems; in others, these doctrines have been or are being modified to mitigate or remove their obstructive aspects. There is a movement in some of the riparian eastern states, too, toward certain aspects of the appropriation doctrine. For, riparian and other landownership principles are not well-suited to comprehensive river basin development, since the water rights must be acquired and merged with other rights involved. The appropriative principle, instead, would seem to be preferable, although it is not per- 
fect, and much serious thought is being devoted to measures that will improve it for this purpose.

While the trend in both the West and the East toward more management and development of watersheds, rivers, and ground water has accelerated the adjustment of water rights doctrines, shifts in the use of water accompanying our expanding economy may also require adjustments, with due regard, of course, to constitutional requirements of due process wherever vested rights are involved. And in this connection, it seems inevitable that the interests of individual water users will come to be represented less and less by individual water rights acquired from the state and more and more by contracts with resource-management districts which will hold mass water rights in trust for the users.

As we look to the future, new technologies may increase water supplies through such innovations as increasing rain and desalting sea water, and these techniques may result in a great change in the economics of water use. In framing a model water code, one that will implement optimal river basin development, all of these possibilities-and, indeed, many others-must be considered. 